\title{
Optimized Models for the Concrete using Flyash and Steel Scrap Waste By-Products
}

\author{
PL. Meyyappan, R. Sutharsan
}

\begin{abstract}
The major issue in the construction industry is to address the development of the suitable building material in a non depleting way to the environmental society. To effectively utilize the industry by-products in the construction sector will bring the cost effective solution and non polluting manner. Hence in this experimental investigation, M30 grade concrete is used in partial replacement of flyash by $0 \%, 10 \%, 20 \%$ and $30 \%$ for evaluating strength parameters. Once the optimum flyash percentage is arrived, then the steel scraps are incorporated in the percentage of $0 \%, 0.5 \%, 1 \%, 1.5 \%$ and $2 \%$ to enhance the strength properties further. As a result, it is profound that the optimum percentage of flyash replaced concrete is $20 \%$ and addition of $1.5 \%$ steel scraps is appropriate in enhancing the strength parameters. Modeling is adopted in arriving relationship for compressive strength with tensile and flexural strength for flyash replacements and addition of steel scraps. All the model equations are well correlated with the experimental results.
\end{abstract}

Keywords : Waste products, Flyash, Steel Scrap, Strength.

\section{INTRODUCTION}

Nowadays the construction industry faces many challenges on environment and economy aspects. In one side, the increase in cost of construction materials. This may be due to non availability and transportation cost. On the other side, the handling the waste by-products such as flyash, coal ash, steel slags, quarry dust, marble dust, steel scraps, waste glass and plastics etc. Many research works have been reported to address these challenges for a mono solution. Some of the works addressed with the utilization of these products in individual manner [Shi3, Udoeyo1, M. Mageswari5, Mannesh Joel7, K.C.Kesharwani12] or in a combined way [Ahamed8, Vasu Krishna9, M. Shahul Hameed4 , P. Aggarwal2, PL. Meyyappan13, R. Hidayawanti14]. Most of the research studies are extensively done with flyash related waste materials due to the advantage of increased workability, enhancing strength properties, resistant to acid attack etc. In order to increase the ductility and durability, fibres are added to the concrete in some studies [S.K. Ahirwar10, PL. Meyyappan13, M. Barbuta11]. But while adding fibres into the concrete, strength will be increased but construction cost will not be comes down. In order to add fibre, waste steel scraps can be better to minimize the cost without compromising the strength parameters. Hence, an attempt is made to utilize the waste by-products into the concrete to the reasonable cost and also

Revised Manuscript Received on December 5, 2019

* Correspondence Author

PL. Meyyappan*, Civil department, Kalasalingam Academy of Research and Education, Krishnankoil, India. Email: meyyappan@klu.ac.in R. Sutharsan, Civil department, Kalasalingam Academy of Research and Education, Krishnankoil, India. Email: r.sutharsan@klu.ac.in to handle the waste products in an utilizable approach. So, in this experimental investigation, two phases will be executed. In first, there is a study of phase flyash replaced concrete and in the second, the addition of steel scraps in the optimum flyash replaced concrete.

\section{MATERIALS AND PROPERTIES}

\section{A. Cement}

The Cement used in this experimental study is of OPC 53 grade confirming to IS 12269:2013. The properties of cement are given in table 1 .

Table- I: Properties of Concrete Materials

\begin{tabular}{|c|l|c|c|c|}
\hline \multirow{2}{*}{ S.no. } & \multirow{2}{*}{ Properties } & \multicolumn{3}{|c|}{ Values for } \\
\cline { 3 - 5 } & & Cement & $\boldsymbol{F A}$ & $\boldsymbol{C A}$ \\
\hline 1 & Specific Gravity & 3.21 & 2.69 & 2.75 \\
\hline 2 & Initial Setting Time & $32 \mathrm{mins}$ & $N A$ & $N A$ \\
\hline 3 & Final Setting Time & $618 \mathrm{mins}$ & $N A$ & $N A$ \\
\hline 4 & Fineness Modulus & $2.35 \%$ & $2.49 \%$ & $7.27 \%$ \\
\hline 5 & Standard consistency & $31 \%$ & $N A$ & $N A$ \\
\hline 6 & Bulking & $N A$ & $25 \%$ & $N A$ \\
\hline 7 & Impact value & $N A$ & $N A$ & $7.2 \%$ \\
\hline 8 & Abrasion value & $N A$ & $N A$ & $19.4 \%$ \\
\hline 9 & Crushing value & $N A$ & $N A$ & $19.8 \%$ \\
\hline
\end{tabular}

\section{B. Fine Aggregate (FA)}

The naturally available river sand having glossy texture and round in shape is used as fine aggregate conforming to requirements of zone II as per IS:383-1970. Fine aggregate passing through $4.75 \mathrm{~mm}$ sieve is considered for this study and its properties are given in table 1 .

\section{Coarse Aggregate (CA)}

The natural rock aggregates having angular and irregular texture passing to $20 \mathrm{~mm}$ sieve and retained on $4.75 \mathrm{~mm}$ sieve is used in this study. The properties of coarse aggregate are as given below in table 1 .

\section{Flyash}

Flyash of class $\mathrm{C}$ category obtained from Tuticorin thermal power plant, Tamil Nadu is used in this study. The flyash passing through 90 micron sieve is used as the replacement material of cement. Thereby, the conventional usage of cement can be minimized.

\section{E. Steel scrap}

Steel scrap is a waste product from lathe industries. The average dimensions are $1 \mathrm{~mm}$ in diameter and $10 \mathrm{~mm}$ in length is used in this work. Its nature is a twisted type.

\section{F. Water}

Portable drinking water is used in this experimental work. 


\section{MIX DESIGN AND INVESTIGATIONS}

In this experimental investigation, M30 grade concrete is used. The design mix proportion arrived as per IS10262:2009 is 1: $1.46: 2.43$ with a W/c ratio of 0.45 . The experimental investigation is planned and executed in two phases. In first phase, properties of flyash replaced concrete and in the second phase flyash and steel scrap blended concrete are investigated. In this first phase, the cement is partially replaced by flyash in different percentages namely $0 \%, 10 \%$ $20 \%$ and $30 \%$. For each replacement of flyash percentage, 12 cubes of size $150 \mathrm{~mm}$ x $150 \mathrm{~mm}$ x $150 \mathrm{~mm}, 12$ cylinders of size $300 \mathrm{~mm} \times 150 \mathrm{~mm}$ and 12 prisms of size $500 \mathrm{~mm} \mathrm{x}$ $100 \mathrm{~mm} \times 100 \mathrm{~mm}$ were cast to test compressive strength, split tensile strength and flexural strength test respectively.

In the second phase, steel scrap of different percentages from $0 \%, 0.5 \%, 1.0 \%, 1.5 \%$ and $2.0 \%$ are added to the total volume of the optimum percentage of flyash replacement on the concrete which is arrived at the first phase. In the second phase, steel scrap is added to the optimum percentage of flyash replaced concrete arrived at the first phase. For each addition of steel scrap percentage, 15 cubes of size $150 \mathrm{~mm}$ x $150 \mathrm{~mm}$ x $150 \mathrm{~mm}, 15$ cylinders of size $300 \mathrm{~mm} \times 150 \mathrm{~mm}$ and 15 prisms of size $500 \mathrm{~mm} \times 100$ $\mathrm{mm} \times 100 \mathrm{~mm}$ were cast to test compressive strength, split tensile strength and flexural strength test respectively. All the tests were carried out in the universal testing machine with a capacity of $2000 \mathrm{kN}$. Out of 81 specimens, 36 specimens and 45 specimens were casted, cured in water and tested for 28 days for first phase and second phase respectively.

\section{EXPERIMENTAL RESULTS AND DISCUSSIONS}

\section{A. Flyash replaced concrete}

Table 2 shows the compressive strength, split tensile strength and flexural strength test results of a flyash replaced concrete in the proportions of $0 \%, 10 \%, 20 \%$ and $30 \%$. The maximum compressive strength of $34.12 \mathrm{~N} / \mathrm{mm} 2$ is attained at the flyash replacement of $20 \%$ for the age of 28 days. Simultaneously at this replacement proportion, the maximum split tensile strength and maximum flexural strength is attained as $1.96 \mathrm{~N} / \mathrm{mm} 2$ and $5.88 \mathrm{~N} / \mathrm{mm} 2$ respectively. From figures 1 to 3 , it is clearly understood that if flyash replacement is increased strength also get increased because the flyash is very fine particles and fill the pores in the concrete by making the concrete highly dense. Beyond $20 \%$ of flyash replacement, the various strength properties tends to decrease may due to the limiting binding property of cement. By replacing cement to flyash upto $20 \%$, the compressive strength increases $15.34 \%$, split tensile strength increases $17.8 \%$ and flexural strength increases $34 \%$ when compared with $0 \%$ of flyash replacement. Thereby the test results clearly indicating the replacement of flyash that the optimum flyash replacement is found to be $20 \%$.

\section{B. 4.2 Flyash and Steel scrap blended concrete}

In the second phase, the different percentages of steel scraps viz. $0 \%, 0.5 \%, 1 \%, 1.5 \%$ and $2 \%$ are added on the optimum $20 \%$ flyash replacement proportion which is found on the first phase of the study and the test results of compressive strength, split tensile strength and flexural strength of the flyash and steel scrap blended concrete are tabulated in table 3 .

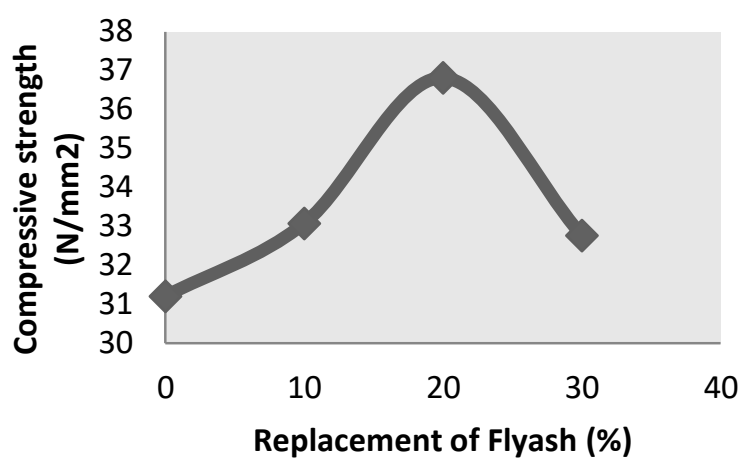

Fig. 1.Compressive strength Vs Flyash replacement.

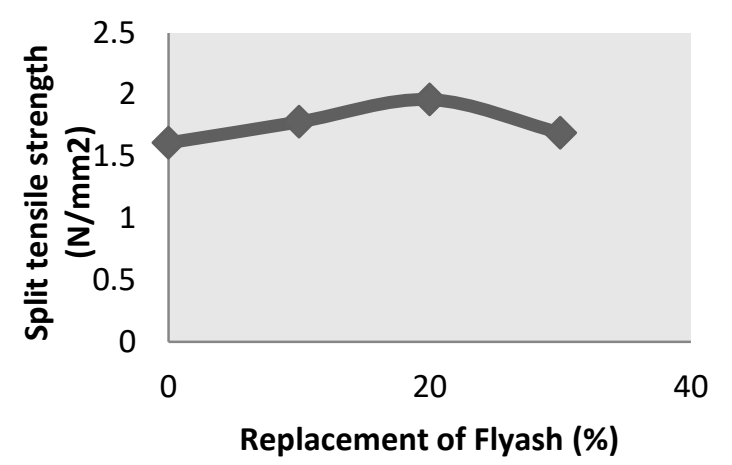

Fig. 2.Split tensile strength Vs Flyash replacement

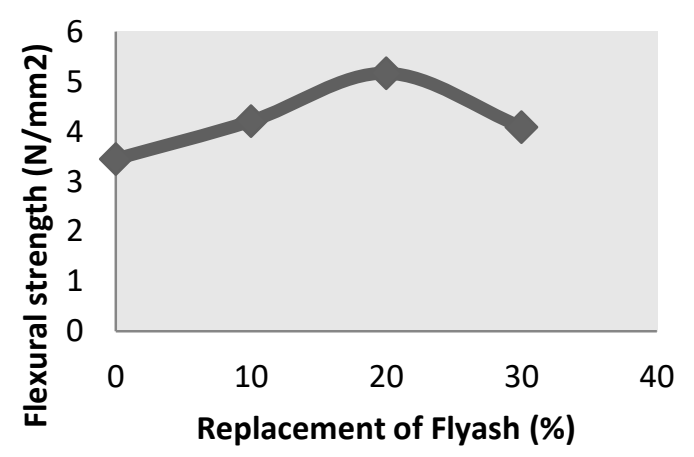

Fig. 3.Split tensile strength Vs Flyash replacement

By the addition of steel scraps upto $1.5 \%$ on the flyash replaced concrete, the compressive strength increases to $37.91 \mathrm{~N} / \mathrm{mm} 2$ from $33.81 \mathrm{~N} / \mathrm{mm} 2$. Simultaneously the split tensile strength and flexural strength increases to 2.35 $\mathrm{N} / \mathrm{mm} 2$ from $1.93 \mathrm{~N} / \mathrm{mm} 2$ and $6.47 \mathrm{~N} / \mathrm{mm} 2$ from 5.61 $\mathrm{N} / \mathrm{mm} 2$ respectively. From figures 4 to 6 , it is clearly understood that strength properties gets declined when addition of steel scraps increased from $1.5 \%$ to $2 \%$.

It seems that, the addition of steel fibres upto $1.5 \%$ on the optimum $20 \%$ flyash replaced proportion is advantages in enhancing strength properties and maintains proportionality. 
This steel scraps occupied the micro-pores of the concrete and thereby preventing the crack propagation process and adding toughness to the concrete. By adding optimum flyash replacement of $20 \%$ and steel scraps of $1.5 \%$, the compressive strength increased to $18 \%$, split tensile strength increased to $32 \%$ and flexural strength increased to $45 \%$. Thereby the test results clearly indicating that the utilization of waste by products flyash and steel scraps plays a vital role in enhancing the mechanical properties of the concrete in an optimum proportion.

Table- II: Test results for flyash replaced concrete

\begin{tabular}{|c|c|c|c|c|c|c|}
\hline S.No & Specimen & $\begin{array}{c}\text { Cement } \\
(\%)\end{array}$ & $\begin{array}{c}\text { Flyash } \\
(\%)\end{array}$ & $\begin{array}{c}\text { Compressive } \\
\text { Strength }\left(\mathrm{N} / \mathrm{mm}^{2}\right)\end{array}$ & $\begin{array}{c}\text { Split Tensile } \\
\text { Strength }\left(\mathrm{N} / \mathrm{mm}^{2}\right)\end{array}$ & $\begin{array}{c}\text { Flexural Strength } \\
\left(\mathrm{N} / \mathrm{mm}^{2}\right)\end{array}$ \\
\hline 1 & FA 0 & 100 & 0 & 31.2 & 1.61 & 3.45 \\
\hline 2 & FA 10 & 90 & 10 & 33.07 & 1.78 & 4.21 \\
\hline 3 & FA 20 & 80 & 20 & 36.81 & 1.96 & 5.17 \\
\hline 4 & FA 30 & 70 & 30 & 32.76 & 1.69 & 4.09 \\
\hline
\end{tabular}

Table- III: Test results for flyash and steel scrap blended concrete

\begin{tabular}{|c|c|c|c|c|c|c|c|}
\hline S.No & Specimen & $\begin{array}{c}\text { Cement } \\
(\%)\end{array}$ & $\begin{array}{c}\text { Flyash } \\
(\%)\end{array}$ & $\begin{array}{c}\text { Steel Scrap } \\
(\%)\end{array}$ & $\begin{array}{c}\text { Compressive } \\
\text { Strength }\left(\mathrm{N} / \mathrm{mm}^{2}\right)\end{array}$ & $\begin{array}{c}\text { Split Tensile } \\
\text { Strength }\left(\mathrm{N} / \mathrm{mm}^{2}\right)\end{array}$ & $\begin{array}{c}\text { Flexural Strength } \\
\left(\mathrm{N} / \mathrm{mm}^{2}\right)\end{array}$ \\
\hline 1 & FAS 0 & 80 & 20 & 0 & 33.88 & 1.93 & 5.61 \\
\hline 2 & FAS 0.5 & 80 & 20 & 0.5 & 34.89 & 2.99 & 5.85 \\
\hline 3 & FAS 1.0 & 80 & 20 & 1.0 & 36.28 & 2.35 & 6.19 \\
\hline 4 & FAS 1.5 & 80 & 20 & 1.5 & 37.91 & 37 & 5.47 \\
\hline 5 & FAS 2.0 & 80 & 20 & 2.0 & 34.19 & & 5.82 \\
\hline
\end{tabular}

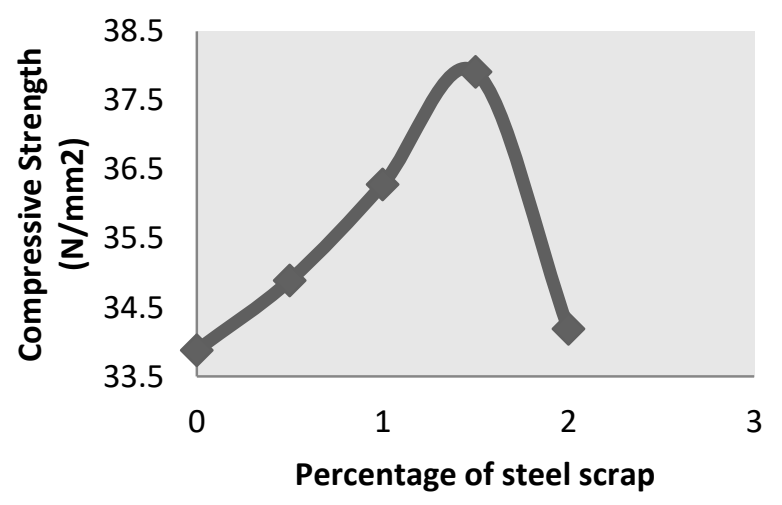

Fig. 4. Compressive strength Vs Percentage of steel scrap

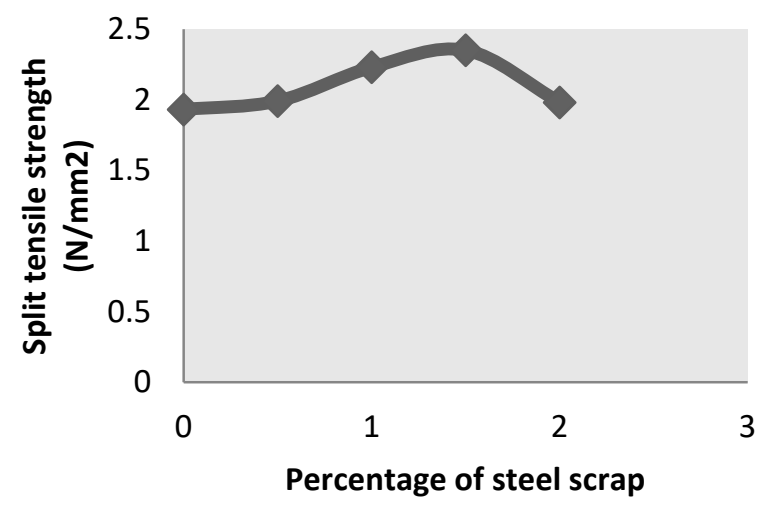

Fig. 5.Split tensile strength Vs Percentage of steel scrap
Fig. 6.Flexural strength Vs Percentage of steel scrap

\section{MODELLING APPROACH AND DISCUSSIONS}

\section{A. Relating strength Properties Vs Flyash}

Equations based on regression analysis are arrived in this study based on the experimental data to validate. Table 4 shows the various types of model equations such as exponential, linear, polynomial $2 \mathrm{~d}$ and $3 \mathrm{~d}$ and their validity levels for relating flyash replacement levels $(\mathrm{Fa})$ with compressive strength (Cs), split tensile strength (Ts) and flexural strength (Fs) respectively. 
Table- IV: Model equations relating strength parameters and flyash replacement

\begin{tabular}{|c|c|c|}
\hline Model Equation & Equation Type & Validity \\
\hline $\begin{array}{c}\mathrm{C}_{\mathrm{s}}=32.15 \mathrm{e}^{0.005 \mathrm{~F}_{\mathrm{a}}} \\
\mathrm{T}_{\mathrm{s}}=1.692 \mathrm{e}^{0.002 \mathrm{~F}_{\mathrm{a}}} \\
\mathrm{F}_{\mathrm{s}}=3.76 \mathrm{e}^{0.007 \mathrm{~F}_{\mathrm{a}}}\end{array}$ & Exponential & $\begin{array}{l}\text { Valid for flyash } \\
\text { replacement of } 10 \%\end{array}$ \\
\hline $\begin{aligned} \mathrm{C}_{\mathrm{s}} & =0.084 \mathrm{~F}_{\mathrm{a}}+32.19 \\
\mathrm{~T}_{\mathrm{s}} & =0.004 \mathrm{~F}_{\mathrm{a}}+1.697 \\
\mathrm{~F}_{\mathrm{s}} & =0.028 \mathrm{~F}_{\mathrm{a}}+3.798\end{aligned}$ & Linear & $\begin{array}{l}\text { Valid for flyash } \\
\text { replacement of } 10 \%\end{array}$ \\
\hline $\begin{array}{l}\mathrm{C}_{\mathrm{s}}=-0.014 \mathrm{~F}_{\mathrm{a}}^{2}+0.528 \mathrm{~F}_{\mathrm{a}}+30.71 \\
\mathrm{~T}_{\mathrm{s}}=-0.001 \mathrm{~F}_{\mathrm{a}}^{2}+0.037 \mathrm{~F}_{\mathrm{a}}+1.587 \\
\mathrm{~F}_{\mathrm{s}}=-0.004 \mathrm{~F}_{\mathrm{a}}{ }^{2}+0.166 \mathrm{~F}_{\mathrm{a}}+3.338\end{array}$ & Polynomial (2d) & $\begin{array}{l}\text { Valid for flyash } \\
\text { replacement of 20\% }\end{array}$ \\
\hline $\begin{array}{l}\mathrm{C}_{\mathrm{s}}=-0.001 \mathrm{~F}^{3}+0.057 \mathrm{~F}_{\mathrm{a}}{ }^{2}-0.228 \mathrm{~F}_{\mathrm{a}}+31.2 \\
\mathrm{~T}_{\mathrm{s}}=-0.008 \mathrm{~F}^{3}+0.002 \mathrm{~F}_{\mathrm{a}}{ }^{2}-0.001 \mathrm{~F}_{\mathrm{a}}+1.61 \\
\mathrm{~F}_{\mathrm{s}}=-0.005 \mathrm{~F}_{\mathrm{a}}{ }^{3}+0.012 \mathrm{~F}_{\mathrm{a}}{ }^{2}-0.008 \mathrm{~F}_{\mathrm{a}}+3.45\end{array}$ & Polynomial (3d) & $\begin{array}{l}\text { Valid for flyash } \\
\text { replacement of } 20 \%\end{array}$ \\
\hline
\end{tabular}

Table- V: Model equations relating strength parameters and steel scraps

\begin{tabular}{|c|c|c|}
\hline Model Equation & Equation Type & Validity \\
\hline $\begin{aligned} \mathrm{C}_{\mathrm{s}} & =34.69 \mathrm{e}^{0.020 \mathrm{~S}_{\mathrm{s}}} \\
\mathrm{T}_{\mathrm{s}} & =0.728 \mathrm{e}^{0.043 \mathrm{~S}_{\mathrm{s}}} \\
\mathrm{F}_{\mathrm{s}} & =5.775 \mathrm{e}^{0.034 \mathrm{~S}_{\mathrm{s}}}\end{aligned}$ & Exponential & $\begin{array}{l}\text { Valid for addition of steel } \\
\text { scraps } 0.5 \% \text { to } 1 \%\end{array}$ \\
\hline $\begin{array}{c}\mathrm{C}_{\mathrm{s}}=0.728 \mathrm{~S}_{\mathrm{s}}+34.70 \\
\mathrm{~T}_{\mathrm{s}}=0.092 \mathrm{~S}_{\mathrm{s}}+2.004 \\
\mathrm{~F}_{\mathrm{s}}=0.208 \mathrm{~S}_{\mathrm{s}}+5.78\end{array}$ & Linear & $\begin{array}{l}\text { Valid for addition of steel } \\
\text { scraps } 0.5 \% \text { to } 1 \%\end{array}$ \\
\hline $\begin{array}{c}\mathrm{C}_{\mathrm{s}}=-2.634 \mathrm{~S}_{\mathrm{s}}^{2}+5.996 \mathrm{~S}_{\mathrm{s}}+33.38 \\
\mathrm{~T}_{\mathrm{s}}=-0.28 \mathrm{~S}_{\mathrm{s}}^{2}+0.652 \mathrm{~S}_{\mathrm{s}}+1.864 \\
\mathrm{~F}_{\mathrm{S}}=-0.525 \mathrm{~S}_{\mathrm{S}}^{2}+1.259 \mathrm{~S}_{\mathrm{s}}+5.517\end{array}$ & Polynomial (2d) & $\begin{array}{c}\text { Valid for addition of steel } \\
\text { scraps } 0.5 \% \text { to } 1.5 \%\end{array}$ \\
\hline $\begin{array}{c}\mathrm{C}_{\mathrm{s}}=-3.82 \mathrm{~S}_{\mathrm{s}}{ }^{3}+8.825 \mathrm{~S}_{\mathrm{s}}{ }^{2}-2.216 \mathrm{~S}_{\mathrm{s}}+33.95 \\
\mathrm{~T}_{\mathrm{s}}=-0.446 \mathrm{~S}_{\mathrm{s}}{ }^{3}+1.06 \mathrm{~S}_{\mathrm{s}}{ }^{2}-0.308 \mathrm{~S}_{\mathrm{s}}+1.931 \\
\mathrm{~F}_{\mathrm{s}}=-0.686 \mathrm{~S}_{\mathrm{s}}{ }^{3}+1.534 \mathrm{~S}_{\mathrm{s}}{ }^{2}-0.216 \mathrm{~S}_{\mathrm{s}}+5.620\end{array}$ & Polynomial (3d) & $\begin{array}{c}\text { Valid for addition of steel } \\
\text { scraps } 0.5 \% \text { to } 1.5 \%\end{array}$ \\
\hline
\end{tabular}

\section{B. Relating strength Properties Vs Steel scraps}

Table 5 shows the various types of model equations such as exponential, linear, polynomial $2 \mathrm{~d}$ and $3 \mathrm{~d}$ and their validity levels for relating addition of steel scraps (Ss) with compressive strength (Cs), split tensile strength (Ts) and flexural strength (Fs) respectively. From table 4 and 5, model equations represents in a simple and complex way with various model types. Among those types of models polynomial equation ( $2 \mathrm{~d} \& 3 \mathrm{~d})$ suits better for up to $20 \%$ of flyash replacement and $1.5 \%$ steel scraps proportion. For lower (up to $10 \%$ ) proportion of replacement of flyash and (up to $1.5 \%$ ) addition of steel scraps, the other model types, namely exponential and linear equations performs in a better way in correlation with the experimental results.

\section{Relating all strength properties}

Based on the experimental test results, the equation 1 and 2 represents the relation of compressive strength with split tensile strength and flexural strength respectively for the flyash replacement proportions. The equation 1 and 2 will be valid for the flyash replacement level up to $20 \%$ and the results in correlation in the range of $\pm 10 \%$.

$$
\begin{aligned}
& \mathrm{T}_{\mathrm{s}}=0.32 \sqrt{\mathrm{C}_{\mathrm{s}}} \\
& \mathrm{F}_{\mathrm{s}}=0.38 \sqrt{\mathrm{C}_{\mathrm{s}}}
\end{aligned}
$$

Similarly 3 and 4 represents the relation of compressive strength with split tensile strength and flexural strength respectively for the addition of steel scraps. The equation 3 and 4 will be valid for the addition of steel scraps up to $1.5 \%$ and the results in correlation in the range of $\pm 12.5 \%$.

$$
\mathrm{T}_{\mathrm{s}}=0.85 \sqrt{\mathrm{C}_{\mathrm{s}}}
$$

\section{CONCLUSION}

The following conclusions are arrived based on this experimental study:

1. Utilization of flyash and steel scraps addressed the two major issues such as disposal of waste by-products and limiting the cost of construction.

2. The $\mathrm{Co} 2$ emission rate can be reduced based on the utilization of waste by-products flyash and steel scraps and thereby the usage of cement content on the concrete can be limited.

3. The optimum flyash replacement was found to be $20 \%$, since there is an increase of $15 \%$ in compressive strength, $18 \%$ in split tensile strength and $34 \%$ in flexural strength.

4. Further, if steel scraps of $1.5 \%$ (optimum) on the $20 \%$ flyash replacement level, the compressive strength, split tensile strength and flexural strength increased by $18 \%$, $32 \%$ and $45 \%$ respectively.

5. Various types of model equations such as exponential, linear, polynomial $2 \mathrm{~d}$ and $3 \mathrm{~d}$ are arrived. Relations of compressive strength with split tensile strength and flexural strength was found for flyash replaced concrete and flyash steel scrap blended concrete. The equations are well correlated in the range of $\pm 10 \%$ to $\pm 12.5 \%$. 


\section{REFERENCES}

1. Udoeyo F.F., Inyang H., Young T.D., Oparadu E.E (2006), “ Potential of wood waste ash as an additive in Concrete.", ASCE-Journal of Materials in Civil Engineering, Vol. 18, No 4.

2. P. Aggarwal, Y. Aggarwal, S.M. Gupta (2007), "Effect of Bottom Ash as Replacement of Fine Aggregates in Concrete, Asian Journal of Civil Engineering (Building And Housing) Vol. 8, (1).

3. Shi C. (2009), "Corrosion of glasses and waste mechanism of concrete containing waste glasses as Aggregates.” ASCE-Journal of Materials in Civil Engineering, Vol. 21. No 10.

4. M. Shahul Hameed, A. S. S. Sekar (2009), "Properties of Green Concrete Containing Quarry Rock Dust and Marble Sludge Powder as Fine Aggregate", ARPN Journal of Engineering and Applied Sciences, Vol. 4( 4).

5. M. Mageswari, B.Vidivelli (2010), "The Use of Sheet Glass Powder as Fine Aggregate Replacement in Concrete", The Open Civil Engineering Journal, Vol 4.

6. Veera Reddy. M (2010), "Investigations onstone dust and ceramic scrap as aggregate replacement in concrete", International Journal of Civil And Structural Engineering, Vol 1(3).

7. Mannesh Joel (2010), "Use of Crushed Granite Fine as Replacement to River Sand in Concrete Production", LeonardoElectronic Journal of Practices and Technologies, Vol 9(17).

8. Ahmad S.F.U (2012), "Properties of concrete containing construction and demolition wastes and fly ash.", ASCE-Journal of Material in Civil Engineering, Vol. 1.

9. Vasu Krishna, G.M. Sabnis (2013), "Utilization of Waste Products andBy-Products in Concrete: The Key to a Sustainable Construction", International Conference on Civil and Architecture Engineering (ICCAE'2013), Malaysia.

10. S.K. Ahirwar, K. Chandraul, M.K. Singh (2017), "Experimental study on concrete using flyash and coconut coir fibre", International Research Journal of Engineering and Technology, Vol.4 (6).

11. M.Barbuta, A.A. Serbanoiu (2017), "Combined effect of flyash and fibers on properties of cement concrete", Procedia, Vol. 181.

12. K.C.Kesharwani, A.K. Biswas (2017), "Experimental study on use of flyash in concrete", International Research Journal of Engineering and Technology, Vol.4 (9).

13. PL. Meyyappan, K.Kumaran, M. Gopalakrishnan and E. Harikrishnan (2018), "Effect of glass fibers, flyash and quarry dust on strength and durability aspects of concrete - An Experimental study", IOP Conference series, Material Science and Engineering, Doi 10.1088.

14. R. Hidayawanti, S. Legino, D. Harjanto (2018), "Optimizing the utilization cement slag and flyash of concrete quality", International journal of advances in mechanical and civil Engineering, Vol. 5 (2)

15. PL. Meyyappan, K.Kumaran, M.Gopalakrishnan and E. Harikrishnan (2018), "Experimental Investigation on the Effect of Silica fume and Pumice stone in Developing Light Weight Concrete", IOP Conference Series: Material Science and Engineering, doi:10.1088/1757-899X/561/1/012064

16. PL. Meyyappan, P. Amuthakannan, R. Sutharsan and M. Ahamed Azik Ali (2019), "Utilization of M-Sand \& Basalt Fiber in Concrete: An Experimental Study on Strength and Durability Properties", IOP Conference Series: Material Science and Engineering, doi:10.1088/1757-899X/561/1/012035

\section{AUTHORS PROFILE}

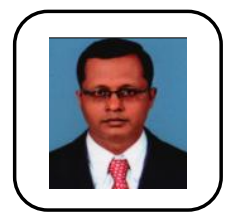

Dr. PL. Meyyappan has completed his graduation and post-graduation from Bharathiyar University and Karunya University respectively. He completed his $\mathrm{PhD}$ from Kalasalingam University. He has 13 years of teaching experience. He has completed 2 sponsored research projects from TNSCST and published more than 25 papers in peer reviewed journals and conferences. He is a life member in ISTE, IEI, IGS, ISET, ISRS. He is serving as Editorial Board Member and Reviewer in various reputed Journals.

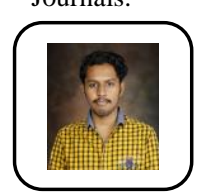

Mr. R. Sutharsan completed his M.E in Structural Engineering in Thiagarajar College of Engineering, Madurai in the year 2016. He completed his Bachelor of Engineering under Anna University in the year 2013. He is working as Assistant Professor in Department of Civil Engineering at Kalasalingam University, Tamilnadu, India

His main thrust research areas is Fiber reinforced concrete. 